\title{
Suriyeli Mülteci Çocukların Kültürel Uyum Sürecinde Okul Psikolojik Danışmanlarına Düşen Rol ve Sorumluluklar
}

\section{School Counselors' Roles and Responsibilities in Cultural Adaptation Process of Syrian Refugee Children}

\author{
Dilek Yelda KAĞNICI, Ege Üniversitesi Eğitim Fakültesi, yelda.kagnici@ege.edu.tr
}

\begin{abstract}
ÖZ. Türkiye Suriye'de yaşanan iç savaş sonrası Suriyeli mültecilere en fazla ev sahipliği yapan ülkedir ve Türkiye'de bulunan Suriyelilerin çoğunun gelecekte Türkiye'de kalacakları düşünülmektedir. Bu yoğun göç deneyimi sağlık, barınma, beslenme, çalışma ve eğitim gibi temel haklar bağlamında çok boyutlu ele alınması gereken bir durumdur. Suriyeli mültecilerin büyük bir kısmını çocuklar ve ergenler oluşturmaktadır. Şu an Geçici Eğitim Merkezleri, Suriyelilerin açtıkları özel okullar ve Devlet okulları aracılığıyla Suriyeli mülteci çocukların bir kısmına eğitim verilmektedir. Çocuklara sağlıklı bir eğitim ortamı sağlayabilmek için başta dil problemi olmak üzere bir çok konunun etkili bir şekilde ele alınması gerekmektedir. Özellikle bu çocukların okula uyum sürecinde okul psikolojik danışmanlarına ciddi rol ve sorumluluklar düşmektedir. Bu rol ve sorumluluklar mültecilerde kültürel uyum süreci ve travma bilgisi, çok kültürü psikolojik danıșma ve hak savunuculuğu yeterlikleri başta olmak üzere okul psikolojik danışmanının bir çok yeterliliğe sahip olmasını gerektirmektedir. $\mathrm{Bu}$ amaçla bu çalışmada mültecilerde kültürel uyum, Suriyeli mülteci çocukların eğitim koşulları ve okula uyum süreçlerinde okul psikolojik danışmanlarına düşen rol ve sorumluklara dair bir bakış açısı sağlanmaya çalışılmıştır.
\end{abstract}

Anahtar Sözcükler: Suriyeli Mülteci Çocuklar, Kültürel Uyum, Okul Psikolojik Danışmanları

\begin{abstract}
Turkey is the most welcoming country to Syrian refugees and currently it is believed that most of the Syrian refugees will permanently stay in Turkey. This condense migration experience should be considered comprehensively regarding health, accommodation, nourishment, work and education rights. Syrian refugee children and adolescents constitute the largest Syrian refugee population. Currently formal education is provided to some of these children through Temporary Education Centers, state schools and private schools owned by Syrians. In order to provide a healthy education first the language problem then the other problems should be carefully taken into consideration. Especially school counselors have critical roles and responsibilities in refugee children's school adaptation process. Therefore, school counselors need to have various competencies including knowledge of acculturation process and trauma, multicultural counseling and advocacy competencies. For this purpose in the present study it is aimed to provide a point of view regarding acculturation process of refugees, education conditions of Syrian refugee children and roles and responsibilities of school counselors in their adaptation process to school.

Keywords. Syrian Refugee Children, Cultural Adaptation, School Counselors
\end{abstract}

\section{SUMMARY}

Purpose and Significance: According to Ministry of Interior Directorate General of Migration Management data, by November 2016 there are 2.743.063 Syrian refugees in Turkey. Among these, 255.106 live in temporary camps and the rest accommodate outside these camps (Ministry of Interior Directorate General of Migration Management, 2016). Since most of the Syrian refugees want Turkish citizenship (Apak, 2015; Erdoğan, 2015), it is believed that many Syrian refugees will permanently stay in Turkey.

Methodology: In order to manage this migration experience, it is important that refugees' cultural adaptation process should be accurately examined. Berry (1997) conceptualizes cross-cultural transition as a series of stress-provoking life changes that draw on adjustive resources and require coping responses. Both individual and situational characteristics such as age, gender, education, preacculturation, status, migration motivation, expectations, cultural distance, personality length of time, acculturation strategies, coping strategies, social support and discrimination may effect adjustment to new culture.

Results: According to the research findings, despite various problems, Syrian refugees are happy to live in Turkey especially those live in eastern cities such as Şanlıurfa, Mardin, Batman, Kilis and Gaziantep (Apak, 2014, 2015; Erdoğan, 2015; Karasu, 2016; Kaya, 2015). However, Syrian refugees 
who live in big cities like İstanbul experience serious problems in terms of employment, accommodation, nourishment and education. In addition, refugees also experience psychological problems due to their pre-migration traumatic experiences such as war, loss of their family and friends (Kirmayer, et al., 2011). As known, host cultures' attitudes towards refugees have an effect on refugees' adaptation process. Unfortunately, positive attitude of Turkish people towards Syrian refuges has been changing to negative ((Deniz, Hülür ve Ekinci, 2016; Erdoğan, 2015; Karasu, 2016; Kaypak ve Bimay, 2016).

Discussion and Conclusion: Although education is one of the fundamental rights of all children, currently of the 1.490.00 Syrian children, 325.000 are enrolled in schools in Turkey (UNICEF, 2016). Formal education is provided to these children through Temporary Education Centers, state schools and private schools owned by Syrians. Schools are the most significant environments for refugee children that social change is experienced (Kopala, Esquivel, \& Baptiste, 1994). It is important to ease the cultural adaptation process for these children in schools. However school managers, teachers, parents and teacher candidates' attitudes towards Syrian refugees are negative in Turkey (Emin, 2016; Kara, Yiğit \& Ağırman, 2016; Mercan \& Bütün, 2016; Sakız, 2016; Topkaya \& Akdağ, 2016). Therefore, school counselors have critical roles and responsibilities to help Syrian refugee children in their adaptation to both school and the new environment. In this respect, comprehensive multidimensional guidance and counseling intervention programs are needed in schools including school managers, teachers, students and parents. Esquivel and Keitel's (1990) culturally sensitive program which includes a) needs assessment, b) in-service training, c) training of school counselors, d) incorporation of interpreters and consultants, e) diagnostic procedures, f) preventive and intervention programs and h) advocacy role might be an effective program while working with Syrian refugee children in schools in Turkey. Turkey has been going through a difficult period related to migration issues. Therefore, all the shareholders in this process should be sensitive and cautious to effectively manage this challenging experience.

\section{Gíriş}

Türkiye krizin başladığı ilk günden itibaren Suriyeli mülteciler için var olan tüm imkânlarını kullanarak mültecilere bașta yaşam hakkı olmak üzere çeşitli haklar sağlamak amacıyla ciddi yatırımlar yapmaktadır. Türkiye Suriye krizinde en büyük katkıyı sağlayan (A World at School, 2015), Suriyeli mültecilere en fazla ev sahipliği yapan ülkedir. İçişleri Bakanlığı Göç İdaresi Genel Müdürlügü̈nün verilerine göre Ekim 2016 itibariyle Türkiye'de geçici koruma kapsamında 2.743.063 Suriyeli mülteci bulunmaktadır. Bunlardan 255.106 bini geçici barınma merkezlerinde, geri kalanlar ise bu merkezler dışında yaşamaktadır (İçişleri Bakanlığı Göç İdaresi Genel Müdürlüğü, 2016).

Suriyeli mültecilere ev sahipliği ilk başlarda geçici bir durum olarak algılanmış olsa da, artık Türkiye'de bulunan Suriyelilerin çoğunun gelecekte Türkiye'de kalacakları düşünülmektedir. Hatta yapılan araştırmalara göre Suriyeli mültecilerin çoğu imkân tanınması dâhilinde Türkiye Cumhuriyeti vatandaşı olmak istemektedir (Apak, 2015; Erdoğan, 2015). Şu an için 22 Ekim 2014'te yürürlüğe giren Geçici Koruma Yönetmeliğine göre Suriyeli mülteciler "geçici koruma" kapsamındadır ve hukuki olarak ne mülteci ne de sığınmacı statüsündedir. Bu makalede zorunlu göç deneyimi yaşamış ve geçici koruma altında olan Suriyeli bireyler mülteci olarak isimlendirilmiştir.

Her ne kadar ülkemizde bu yoğun göç deneyimi etkili bir şekilde yönetilmeye çalışılsa da, siyasi uyum, iş uyumu, aile birliği, sağlık, eğitim, kalıcı ev, vatandaşlık hakları ve ayrımcılık olmak üzere 8 başlık altında ülkelerin göç ve entegrasyonu politikalarının incelendiği Göç ve Entegrasyonu Politika Indeksi'ne (Migrant Integration Policy Index, 2015) göre Türkiye 38 ülke arasında entegrasyon politikaları açısından son sırada yer almaktadır. Kanada, Amerika gibi göç konusunda daha deneyimli ülkelere göre nispeten yolun başında olan bir ülke için anlaşılır olsa da, bu bulgunun uyarı mahiyetinde ele alınması gereken bir durum olduğu düşünülmektedir.

Görüldüğü gibi sözü edilen değerlendirmede ele alınan temel başlıklardan biri eğitimdir. Eğitim tüm çocukların en temel hakkıdır. Bu bağlamda Türkiye'de de Suriyeli mülteci çocuklara eğitim olanakları sağlanmaktadır. Bu makalede ilk olarak, mültecilerin kültürel uyum süreci, bu süreci zorlaştıran ve kolaylaştıran faktörlere dikkat çekilmesi, ardından Suriyeli mülteci çocukların 
eğitim koşulları irdelenerek çocukların okula uyum sürecinde eğitim kurumlarının en temel öğelerinden biri olan okul psikolojik danışmanlarına düşen rol ve sorunlulukların neler olabileceğine dair bir bakış açısının sunulması amaçlanmıştır.

\section{Mültecilerde Kültürel Uyum ve Suriyeli Mültecilerin Kültürel Uyumu}

Berry'e (1997) göre kültürlerarası geçiş stres yaratan ve uygun baş etme becerilerinin kullanılmasına gerek duyulan bir süreçtir. Mülteciler, göçmenler, uluslararası öğrenci ve çalışanların kültürleşme sürecini etkileyen faktörler arasında farklılıklar gözlense de tüm bu grupların benzer bir uyum sürecinden geçmekte olduğu öne sürülmektedir (Berry ve Sam, 1996). Psikolojik kültürleşme süreci beş aşamadan oluşmaktadır. İlk aşama kültürlerarası bir temasın yaşanması aşamasıdır. İkinci aşama yaşanılan deneyimlerin algılanmasıdır. Bu aşamada yaşanılan deneyimler gözden geçirilmekte ve değerlendirilmektedir. Üçüncü aşamada yaşanılan deneyimlere anlamlar verilmekte ve farklı baş etme yöntemleri kullanılmaktadır. Dördüncü aşama yaşanılan stresin ilk tepkilerinden oluşmaktadır. Deneyime yüklenen anlama göre stres düzeyi de değişmektedir. Son aşamada ise bir uyum söz konusudur. Bireyler kültürleşme sürecine yaş, cinsiyet, farklı kültürle temas nedenleri, kişilik özellikleri, eğitim durumu, statü ve kültürler arası benzerlikler gibi bir takım faktörlerin etkisiyle başlamaktadır. Kültürleşme süreci esnasında ise yeni kültürle temasın süresi, sosyal destek, baş etme becerileri, kültürleşme tutumları ve algılanan ayrımcllık gibi faktörler uyum sürecini etkilemektedir (Berry, 1997).

Yapılan çalışmalar kültürel uyum sürecindeki tüm zorluklara rağmen Suriyeli mültecilerin genel olarak Türkiye'de olmaktan nispeten memnun olduğunu işaret etmektedir (Apak, 2014, 2015; Erdoğan, 2015; Karasu, 2016; Kaya, 2015). Özellikle göçün yoğun olduğu Şanlıurfa, Mardin, Batman, Kilis, Gaziantep gibi güney doğu illerinde yaşayan Suriyeli mültecilerin uyum sürecinin nispeten daha rahat olduğu görülmektedir. Suriyeli mültecilerin bölgede akrabalarının olması (Apak, 2014; Deniz, Hülür ve Ekinci, 2016; Kaypak ve Bimay, 2016), dini inançlarını rahat yaşamaları (Apak, 2014), bölge halkı ile ilişki kurmakta zorlanmamaları (Apak, 2014), ayrımcılığa maruz kalmamaları (Apak, 2014), yabancılık duygusu yaşamamaları (Kaya, 2015) ve genel olarak beklentilerinin karşılanmış olması (Apak, 2015) bu durumun temel nedenleri olarak görülmektedir. Bölge dişında İstanbul gibi şehirlerde yaşayan Suriyeli mültecilerin ise eğitimden, barınmaya, çalışma haklarından, kamu hizmetlerine erişime kadar bir takım ciddi sıkıntılar yaşadıkları görülmektedir (Suriye'den İstanbul'a Gelen Sığınmacıları İzleme Platformu, 2013). Suriyeli mültecilerin yaşadıkları en temel sorunların başında dil problemi gelmektedir (Apak, 2014, 2015, Buz, 2008; Deniz, Hülür ve Ekinci, 2016; Karasu, 2016). İşsizlik ve niteliksiz işlerde çalışma (Apak, 2014; Deniz, Hülür ve Ekinci, 2016; Karasu, 2016), sosyal dışlanma, barınma, beslenme ve çocukların okula gitmemesi de diğer sorunlar arasında yer almaktadır (Karasu, 2016, Suriye'den İstanbul'a Gelen Sığınmacıları İzleme Platformu, 2013)

Mültecilerin kültürel uyum süreçlerinde diğer kültürel gruplardan farklı olarak ele alınması gereken başka faktörler de bulunmaktadır. Mültecilerin ülkelerinden ayrılma durumunda bir gönüllülük bulunmamaktadır, ayrılış daha çok bir zorunluluk niteliğindedir. Bu da bir anlamda bu ciddi yaşamsal değişimin ani gelişmesini beraberinde getirmektedir. Mülteciler ayrıca genellikle göç öncesi travmatik yaşantılara, kayıplara ve zorlu yaşam koşullarına maruz kalmaktadır (Kirmayer ve diğ., 2011). Diğer bir ifade ile doğasında stres olan kültürel uyum sürecine mülteciler hâlihazırda travmatik yaşantılara maruz kalmış bir durumda dâhil olmaktadır. Yapılan bir çalışmada İ̉ran, Irak ve Filistin'den Türkiye'ye gelen 19-50 yaşları arasındaki mültecilerin \% 12'sinde travma sonrası stres bozukluğu tespit edilmiştir (Yaman, Kut, Yaman, ve Ungan, 2002). Başka bir çalışmada da Türkiye'deki kamplarda kalan Suriyeli çocukların \% 49'unun depresyon ölçeğinden yüksek, \% 36'sının ise klinikte düzeyde depresyon puanı aldıkları, \% 12,7 - 25,8'inin baş ağrısı, karın ağrısı, ellerde, kollarda ağrı gibi psikosomatik sorunlar yaşadıkları görülmüştür (Özer ve Şirin, 2013). Yine Şanlıurfa Akçakale Mülteci Kampı'ndaki 450 kişinin katıldığı başka bir araştırmada benzer şekilde mültecilerden 87 kişide (\% 19,3) şiddetli anksiyete belirtileri görülürken; 40 kişide $(\%$ 8,9) şiddetli depresyon belirtileri bulunmuştur (Önen, Güneş, Türeme ve Ağaç, 2014). Tüm bu bulgular mültecilerin ruh sağlığı açısından da sorunlar yaşadıklarını ortaya koymaktadır.

Kültürel uyum sürecinde yerel toplumun mültecilere yönelik tutumları da kültürel uyum sürecinde önemli bir yere sahiptir (Berry, 1997). Türkiye'deki duruma bakıldığında özellikle göçün başladığı ilk yıllarda toplumun Suriyeli mültecileri komşuluk, zor durumda olana yardım etme, din 
kardeşliği gibi temel değerler çerçevesinde değerlendirdiği ve Suriyeli mültecilere yönelik olumlu bir tutum içinde olduğu görülmektedir (Erdoğan, 2015, Karasu, 2016). Ancak son zamanlarda kalınan sürenin uzamış olması, mültecilere tanınan haklar (Karasu, 2016), nüfusun artışı ile ortaya çıkan kira ve ev fiyatlarında artışlar (Karasu, 2016; Kaypak ve Bimay, 2016), çevre kirliliği (Kaypak ve Bimay, 2016), mültecilerin dilencilik yapmaları (Erdoğan, 2015), istihdamda yaşanan sıkıntılar (Erdoğan, 2015, Karasu, 2016, Kaypak ve Bimay, 2016), toplumun huzur ve düzeninin bozulması endişesi ve Suriyeli mültecilere vatandaşlık verilmesinin gündemde olması (Erdoğan, 2015) gibi nedenlerle toplumun Suriyeli mültecilere yönelik olumsuz bir tutum içine girmeye başladığı göze çarpmaktadır (Deniz, Hülür ve Ekinci, 2016; Erdoğan, 2015; Karasu, 2016; Kaypak ve Bimay, 2016). Nitekim yapılan yeni bir çalışma, toplumun Suriyeli mülteciler ile arasına kültürel bir mesafe koyduğunu, mültecilere vatandaşlık verilmesine hiç sıcak bakmadığını ortaya koymaktadır (Erdoğan, 2015).

Olumsuza dönen tutumda algıların da bir payı olduğu düşünülmektedir. Suriyelilerin hırsızlık, fuhuş, gasp, kamu malına zarar verme gibi suçlarla oldukça yaygın bir şekilde ilişkilendirilmelerine rağmen (Karasu, 2016) Suriyelilerin suça karışma oranlarının yerel halkın suç oranlarından çok daha düşük olduğu görülmektedir (Erdoğan, 2015). Mültecilerle ilgili yaşanan bir diğer sorun ise, genç yaştaki bekâr ve dul kadınların varlığıdır. Bu durum, yerel halk arasında boşanma oranlarının artabileceği endișelerini doğurmakta; aile içi çatıșmalara ve ahlaksal kaygılara neden olabilmektedir (Kaypak ve Bimay, 2016). Özellikle bölgede yaşayan kadınların Suriyeli mülteci kadınları evlilikleri açısından bir tehdit olarak algıladığı ve depresyona varan sorunlar yaşadıkları saptanmıştır (Erdoğan, 2015). Diğer bir sorun ise istihdam ile ilgilidir. Man'a (2016) göre Türkiye'de dünya ortalamasının üstünde bir işsizlik bulunmaktadır ve bu durum son dört beş yılda ortaya çıkan bir durum değildir. İstihdam ile ilgili yerel halk, kendilerinin işten çıkartılıp yerlerine Suriyelilerin alındığını düşünmekte iken işverenler ise Suriyelilerin yerel halkın iş fırsatlarını elinden almadığını, tersine vasıfsız işgücü gerektiren iş kollarındaki açığı kapattığını öne sürmektedir (Man, 2016). Ancak istihdam konusunun mülteci ve göçmenlere yönelik tutumu etkileyen temel değișkenlerin başında geldiği (Ward, Bochner ve Furhnam, 2001) düşünüldüğünde, bu bulguların çok dikkatli bir şekilde ele alınması gerektiği aşikârdır. Mülteci ve göçmenlerin ekonomik uyumunu ve dolayısıyla kültürel uyumunu sağlamak için istihdam edilmeleri gereklidir. Diğer taraftan yerel halkın da mülteci ve göçmenleri istihdam konusunda risk faktörü olarak görmemeleri için istihdam politikalarının özenli yürütülmesi gerektiği düşünülmektedir.

\section{Suriyeli Mülteci Çocukların Eğitim Koşulları}

Ülkemizde 1,490,033 Suriyeli mülteci çocuk bulunmaktadır ve okula kayıtlı öğrenci sayısı 325.000'dir (UNICEF, 2016). İlk yıllarda durumun geçici olacağı düşünülerek eğitim sadece kamp içindeki Suriyeli çocuklara yönelik hazırlanmıștır. Ancak 23 Eylül 2014 tarihinde 2014/21 sayılı Yabancılara Yönelik Eğitim-Öğretim Hizmetleri başlıklı genelge ile Suriyeli mülteci çocuklara sunulacak eğitim hizmetleri güvence altına alınmıştır. Şu an Suriyeli mülteci çocuklara eğitim hizmetleri kamp içi, kamp dışı (Geçici Eğitim Merkezleri ve Devlet Okulları) ve Suriyelilerin açtığı özel okullar aracılığıyla verilmektedir. Geçici Eğitim Merkezleri (GEM), okul çağındaki Suriyeli çocuklara ve gençlere Suriye müfredatına bağlı kalarak Arapça eğitim veren ilköğretim ve ortaöğretimi kapsayan eğitim merkezleridir (Milli Eğitim Bakanlığı, 2014). Bu merkezlerdeki eğitimde uygulanan müfredat Suriye müfredatıdır ve bu merkezlerde Suriyeli gönüllü öğretmenler eğitim vermektedir. Bu öğretmenlere UNICEF ve PTT işbirliği ile yürütülen proje kapsamında ödeme yapılmaktadır (Emin, 2016).

Suriyeli mülteci çocukların eğitimleri konusunda çeşitli kurum ve kuruluşlar da çaba harcamaktadır. Bu kurumlardan biri olan UNICEF'in 2016 Nisan raporuna göre a) krizin başlangıcından bu yana 43 okul ve GEM inşa edilmiş ve 177 tanesi yenilenmiş veya yeniden donatılmış, b) Suriyeli öğrencilerin Türkçe, İngilizce ve Arapça olarak, derslerindeki notlarını ve okula devam durumlarını izlemek ve mezuniyet belgelerini düzenlemek için Yabancı Öğrenci Bilgi İşletim Sistemine (YÖBİS) teknik ve finansal destek sağlanmış, c) Kamplarda bulunan 1.300'den fazla öğrenciye Türkçe dil kursu verilmiş ve d) Kamplarda ve kamp dışında görev yapan yaklaşık 10,000 Suriyeli gönüllü öğretmene olağanüstü durumlarda sürdürülebilir eğitim, zorlu koşulların üstesinden gelme becerileri ve psiko-sosyal destek eğitimi verilmiştir (UNICEF, 2016). 
Tüm çabalara rağmen Mülteci çocukların eğitimlerine ilişkin bazı sorunlar devam etmektedir. Suriyeli mülteci ebeveynler eğitim hakkından faydalanmamaları ve okula gidememeleri nedeniyle çocuklarının Türkiye'de büyümesinden endişe duymaktadır (Apak, 2015). Her ne kadar gerek GEM, gerek özel okullar, gerekse devlet okullarında eğitim alma haklarına sahip olsalar da ailelerin ekonomik nedenlerden dolayı çocuklarının çalışmasını istemeleri ya da çocuğun uzun süre eğitime ara vermesinden kaynaklı okula gitmek istememesi nedeniyle Suriyeli mülteci çocukların çok büyük bir oranı eğitim almamaktadır (Erdoğan, 2015). Eğitim alanların ise dil engeli bașta olmak üzere bir takım sıkıntılar yaşadığı gözlemlenmektedir. Mülteci çocukların özellikle devlet okullarına yerleştirilmiş olması bu eğitim kurumlarında da sıkıntılara neden olmaktadır. Bazı okul yöneticilerinin ve öğretmenlerin Suriyeli mülteci çocukların devlet okullarında eğitim almaları ile ilgili olumsuz tutum içinde oldukları görülmektedir (Emin, 2016; Sakız, 2016). Sakız'ın (2016) araştırması okul yöneticilerinin çoğunun son yıllardaki göç dalgasıyla oluşan farklılığın kendi okullarının akışını bozduğunu, mevcut öğrencilerin düzenini aksattı̆̆ını, mülteci çocukların kendi okullarında eğitim görmesine sıcak bakmadığını, genel olarak da okullarda mevcut homojen öğrenci yapısının devam etmesini savunduğunu ortaya koymuştur. Benzer şekilde velilerin de olumsuz tutum içinde olduklarına dair araştırma bulguları da mevcuttur. Mercan ve Bütün'ün (2016) okul öncesi eğitim kurumlarındaki Suriyeli mülteci çocukların karşılaştıkları sorunları inceledikleri çalışmada, temel ihtiyaçlarının karşılanması noktasında sorun yaşayan mülteci çocukların sınıf ortamında daha çok dışlandığı, ailelerin sığınmacı çocuklarla, çocuklarının aynı ortamda olmalarından rahatsız oldukları ve öğretmenlerin de Suriyeli çocukları tam olarak kendi öğrencileri gibi benimsemedikleri görülmüştür. Öğretmen adaylarıyla yapılan bir iki çalışmada da aşırı nüfusa sahip olmaları, çevreyi kirletmeleri, dilencilik yapmaları, Türkiye'ye yük oldukları ve ülkenin huzurunu bozduklarını düșünmeleri gibi nedenlerle öğretmen adaylarının Suriyeli mültecilere yönelik olumsuz bir tutum içinde olduğu saptanmıştır (Kara, Yiğit ve Ağırman, 2016; Topkaya ve Akdağ, 2016). Hatta öğretmen adaylarının \% 55.5'nin Suriyeli mülteciler ile aynı mahallede yaşamak istememeleri Topkaya ve Akdağ'ın (2016) araştırmasının çarpıcı sonuçlarında biridir. Geleceğin öğretmenlerinin de olumsuz bir tutum içinde olması, mülteci çocukların okullara uyumunu zorlaştırabilecek bir durum ile karşı karşıya kalabileceğinin bir işareti olarak ele alınmalıdır.

\section{Kültürel Uyum Sürecinde Okul Psikolojik Danışmanının Yeri}

Çocuklar için kültürel uyum sürecinde sosyal değişimin en bariz yaşandığı ortamlardan biri okullardır çünkü okullar mülteci çocukların baskın kültür ile doğrudan karşı karşıya kaldığı yegâne ortamlardan biridir (Kopala, Esquivel ve Baptiste, 1994). Rousseau ve Guzder'in (2008) de altını çizdiği gibi okullar mülteci çocukların kendilerini geleceğe taşıyabilmeleri ve toplumla bağ kurmaları için bir köprü görevi görmektedir. Oysaki görüldüğü gibi eğitim ortamlarında çok boyutlu ciddi sorunlar yaşanmaktadır. Bir tarafta Suriyeli mülteci çocuklar ve ailelerinin kaygıları, diğer yanda ise eğitim kurumlarında okul yöneticileri, öğretmenler ve hatta velilerin kaygıları bulunmaktadır. 2011 yılından bu yana Türkiye'de 200 bini aşkın Suriyeli bebeğin doğduğunu ve yakın gelecekte Suriyeli mültecilerin ülkelerine dönmelerinin pek olasılık dâhilinde olmaması göz önünde bulundurularak (Erdoğan, 2015), eğitim kurumlarında sağlıklı bir okul iklimin oluşturulması için ciddi emek verilmesi gerektiği aşikârdır. Bu bağlamda okul psikolojik danışmanlarının eğitim ortamlarındaki bu olumsuz algının kırılması için etkin bir şekilde sorumluluk üstlenmesi kaçınılmazdır.

Okullarda sağlıklı işleyen bir eğitim sistemi oluşturmak hem toplum hem de mülteci çocuklar için önemlidir. Mülteci çocukların okula uyumunu kolaylaştırmak için durumu çok boyutlu ele almak gerekmektedir. Ancak, ilk olarak Suriyeli mülteci çocukların dil probleminin çözülmesine öncelik verilmesi gerekmektedir. UNICEF'in raporuna göre kamplardaki çocuklar Türkçe eğitimi almaktadır ancak kamp dışında yaşayan mülteci sayısı daha fazla olduğundan devlet okullarına devam eden mülteci çocukların bu eğitimden geçmemiş olma olasılığı oldukça yüksektir. Bu nedenle okullarda ilk olarak mülteci çocuklara Türkçe eğitimin verilebileceği bir düzenlemeye gidilmesi gerekmektedir. Buna ek olarak mülteci çocukların anadiline hâkim öğretmenlerin de okullarda istihdam edilmesi süreci kolaylaştırıcı olacaktır. Bu bağlamda yürütülen çalışmalar kapsamında Milli Eğitim Bakanlığı "Suriyeli Çocukların Türk Eğitim Sistemine Entegasyonu Desteklenme Projesi (PICTES)" kapsamında Mart 2017 itibariyle geçici süreli olarak psikolojik danışmanlarla birlikte Türkçe öğreticilerini de istihdam etmeye başlamıştır (Hayatboyu Öğrenme Genel Müdürlüğü, 2017). 
Okuldaki yöneticileri, öğretmenleri, okuldaki yerel öğrencileri, ailelerini, mülteci çocukları ve mülteci çocukların ailelerini kapsayan programlara ihtiyaç vardır. Bu bağlamda okul psikolojik danışmanı, psikolojik danışmadan, krize müdahaleye, veli görüşmelerinden konsültasyona, izleme çalışmalarına kadar tüm psikolojik danışma hizmetlerini programa dahil etmelidir. Nitekim terapi, krize müdahale, konsültasyon ve aile eğitimi gibi boyutların bir arada olduğu AMIGO programının göçmen çocukların okula uyumunu kolaylaştırdığı görülmüştür (Greenberg, Garrison, Roy ve Azar, 1999). Esquivel ve Keitel'in önerdiği (1990) okul psikolojik danışmanlarının a) çok kültürlük konusunda eğitim alması, b) ihtiyaç analizi yapması c) tanılama süreçleri geliştirmesi, d) hizmet içi eğitim sunması, e) aracı/danışmanları sürece dahil etmesi, f) önleyici ve müdahale programları geliştirmesi ve h) hak savunucu olmasını kapsayan kültüre duyarlı psikolojik danışma programının Suriyeli mülteci çocuklarla çalışmak için de işlevsel olacağı düşünülmektedir.

Etkili yardım sunabilmek için ilk olarak okul psikolojik danışmanlarının farklı kültürel özelliklere sahip çocuklar ve ergenlerle çalışma konusunda eğitimli olması gerekmektedir. Okul psikolojik danışmanlarının her şeyden önce mülteci çocuklarla etkin bir şekilde çalışabilmek için çok kültürlü psikolojik danışma ve hak savunuculuğu yeterliklerine sahip olması şarttır. Psikolojik danışmanların olası önyargılarını, etkin yardım sunmasını engelleyebilecek inanç ve tutumlarını fark etmesi ve bunları çözümlemesi gerekmektedir. Okul psikolojik danışmanları "Farkı kültürel gruplara yönelik önyargılarım var mı? Varsa temeli ne? Ahlaki kimliğim ne düzeyde? Sosyal baskınlık yönelimim ne? Kültürel empati düzeyim ne?" gibi soruların cevabını dürüst bir şekilde kendilerine verebilmelidir. Okul psikolojik danışmanlarının genelde mültecilerin, özelde mülteci çocuk ve ergenlerin kültürel uyum süreci hakkında detaylı bilgiye sahip olması görüldüğü gibi oldukça önemlidir. İlgili tüm faktörleri bilmek uyum sürecinin kolaylaştırılmasında etkin rol oynayacaktır. Belirtildiği gibi mültecilerde travma oldukça yaygındır. Etkili yardım sunabilmek için okul psikolojik danışmanlarının travma konusunda da eğitim ve deneyime sahip olması gerekmektedir.

İhtiyaç analizi kapsamında okul psikolojik danışmanları ilk olarak mülteci çocukların uyum süreçlerini takip etmelidir. Sınıf etkinlikleri, küçük gruplar ve bireyle psikolojik danışma aracılığıyla psikolojik danışmanların ihtiyaçları belirlemesi mümkündür (Kopala, Esquivel ve Baptiste,1994). Kültürel uyum sürecindeki temel ve özel faktörler bağlamında bir değerlendirme yapmak ve gerek olması halinde tanılama süreçleri gelişmek ilk önce yapılması gerekenler arasında yer almaktadır. Mülteci çocuklarda yaygın olarak depresyon, travma sonrası stres bozukluğu, kaygı bozuklukları gibi rahatsızlıkların doğru bir şekilde tanılanması ve çocuklara uygun terapi ve ilaç desteği sağlanması açısından gereklidir. Tanılama sürecinin sağlıklı bir şekilde yürütülmesi için özellikle yoğun göç almış şehirlerde ruh sağlığı uzmanlardan oluşan bir ekibin kurulmasının isabetli olacağı düşünülmektedir. Mülteci çocuklar bu süreçte arkadaş ve aile kaybı, ayrılma kaygısı, yeni ortama uyum sağlama zorlukları yaşamaktadır ve bu yaşantılar çocuklarda içine kapanmaya, saldırganlığa ve/veya maskelenmiş depresyonun göstergesi olabilen davranış bozukluklularına yol açabilmektedir (Kopala, Esquivel ve Bastiste, 1994). Mülteci çocuklarla yürütülen terapi süreçlerinde travma odaklı bilişsel davranışçı terapi (Demirbaş ve Bekaroğlu, 2013), sanat terapisi (Rousseau ve Lacroix, 2003) gibi farklı yöntemler ve yaklaşımlar kullanılmaktadır. Psikolojik danışmanların bu tür çalışmaları takip etmesi, kendini farklı yaklaşımlar konusunda geliştirmesi ve okul ortamında kullanabilecek müdahale yöntemlerini hayata geçirme konusunda çaba sarf etmesi gerekmektedir.

Psikolojik danışmanların diğer bireyleri de kültürel duyarlılık konusunda eğitme sorumluluğu bulunmaktadır (Gibson ve Mitchell, 2011). Okul psikolojik danıșmanlarının temel ișlevlerinden biri olan konsültasyon da burada devreye girmektedir. Okul psikolojik danışmanları okuldaki yöneticiler, öğretmenler ve görevlilerin kültürel duyarlılık konusunda gelişmelerine hizmet içi eğitimlerle destek olmalıdır. 21.yüzyılda artık okullar insan haklarına, çeşitliliğe ve eşitliğe önem veren, okul ortamındaki tüm bireylerin etkin bir şekilde eğitime dâhil olması için çaba sarf edildiği kültüre duyarlı bir eğitim sağlamak durumundadır (Johnson, 2003). Çok kültürlü eğitim anlayışının temelinde öğrencilerin farklı ırk, etnik köken, sınıf, cinsiyet, dil, inanç sistemi, deneyim, cinsel tercih ve politik görüşe sahip olabileceklerini düşünmek, kabul etmek, öğretim ortamını düzenlerken bunları dikkate almak ve bu farklılıkları tartışmaya açık olmak, kültürel zenginliği sınıf ortamına taşımak önemli yer teşkil etmektedir (Başbay ve Bektaş, 2009). Çokkültürlülüğün eğitim programlarına bütünleştirilmesi için Banks (2016) takip edilmesi gereken a) içeriğin bütünleștirilmesi, b) önyargıların azaltılması, c) eşitlik eğitimi ve d) okul kültürünün 
güçlendirilmesinden oluşan dört adım önermektedir. Bu adımlar dikkate alındığında özellikle önyargıların azaltılması ve eşitlik eğitimi konularında okul psikolojik danışmanlarına önemli görevler düşmektedir. Kültürel olarak farklılıkları olan mülteci çocukların okula uyumunun sağlanmasında özellikle öğretmenlerin çok kültürlü eğitim yeterliklerine sahip olması gerekmektedir. Oysaki yapılan birkaç çalışma (Emin, 2016; Kara, Yiğit ve Ağırman, 2016; Mercan ve Bütün, 2016; Sakız, 2016; Topkaya ve Akdağ, 2016) okul yöneticilerinin, öğretmenlerin ve hatta öğretmen adaylarının Suriyeli mültecilere yönelik olumsuz bir tutum içinde olduğunu ortaya koymuştur. Bu nedenle mülteci çocukların eğitiminde doğrudan rol oynayan öğretmenlerin desteğe ihtiyacı olabileceği göz önünde bulundurulmalıdır.

Mülteci çocukların uyum süreçlerini sadece yerel kaynaklar ile kolaylaştırmaya ve düzenlemeye çalışmak her zaman olumlu sonuçlar vermemektir (Rousseau ve Guzder, 2008). Mülteci çocuklarla çalışırken etkililiği arttırmak adına "aracı/danışman" kullanmak etkili olmaktadır (Pottie ve diğ. , 2011). Bu, özellikle çatışmalı göç öncesi deneyime sahip mülteci çocukların eğitim ihtiyaçlarını ortaya koymak için kullanılabilecek uygun bir yöntemdir (Yohani, 2013). Özellikle kendi uyum süreçlerini tamamlamış olan mülteciler, ailelere ve çocuklara sosyal destek sağlayabilmektedir ve bunun neticesinde aileler aidiyet ve kabul duygusu yașatabilmektedir (Kopala, Esquivel ve Baptiste, 1994). Bu nedenle Suriyeli gönüllü öğretmenler ile işbirliği içinde çalışmak süreci herkes adına kolaylaştıracak, bir takım kültürel engellerin önüne geçilmesine katkı sağlayacak ve ayrıca geliştirilecek müdahale ve önleme programlarına katkı sağlayacaktır. Bu programlarda Suriyeli mülteci çocuklar için iletişim becerileri, karar verme becerileri ve sosyal becerilere yer vermek, ayrıca uyum sağlamaya çalıştıkları yeni kültür hakkında çocukları bilgilendirmek uygun olacaktır (Kopala, Esquivel ve Baptiste, 1994). Nitekim kültür öğrenme yaklaşımına göre ev sahibi kültürü öğrenmek uyumu kolaylaştırmaktadır (Furnham ve Bochner, 1986). Okulda mülteci çocuklara yönelik planlanacak hizmetler kadar yerel çocuklar için de karşılıklı uyum sürecini kolaylaştıracak programlar hazırlamak son derece önemlidir. Gibson ve Mitchell'in (2011) belirttiği gibi okul psikolojik danışmanları özellikle çocukların ilkokul yıllarında kültürel ayrımcılık ve önyargı ile mücadelelerine etkin olarak katılmalıdır. Bu amaç doğrultusunda okul psikolojik danışmanı yerel öğrencilere insan ilişkileri beceri eğitimi, kültürel farkındalık, çok kültürlü etkileşim eğitimleri düzenlemeli ve rehberlik etkinliklerinde kültürel çeşitlilik konularına yer vermelidir. Ayrıca akran rehberliği de devreye sokularak, kültürel farklılıklar konusunda eğitim alan bazı öğrencileri mülteci çocuklara uyum süreçlerinde destek sağlayabilecek şekilde yetiştirmek (Kopala, Esquivel ve Baptiste, 1994) de yapılabilecekler arasında yer almaktadır.

Psikolojik danışmanlar için önemli bir mesleki görev olan hak savunuculuğu çevresel değişimler yapabilmek için danışanlar adına konuşma ve eyleme geçme olarak tanımlanmaktadır (Lewis ve Bradley, 2000). Her ne kadar psikolojik danışma kültürel uyum sürecinde önemli ve gerekli hizmetlerden biri olsa da, okul psikolojik danışmanları bunun ötesine geçmek ve Suriyeli mülteci çocukların hak savunucusu olmak durumundadır. Psikolojik danışmanlar mülteci çocukların yaşadıkları sorunları belirlemek, bunları üst yönetimlerle paylaşmak, mülteci çocukların sesi olmak, kamuoyunu bilgilendirmek, var olan sistemlere etki etmek için çalışmalıdır. Hak savunuculuğu yeterlikleri psikolojik danışmanlara çerçeve sunacak temel bir kaynak niteliğindedir (ACA Advocacy Competencies, 2003). Empati, güvence ve hak savunuculuğunun mültecilerde iyileşme sürecinin temel öğeleri (Potttie, ve diğ., 2011) olduğu göz önünde bulundurulduğunda, okul psikolojik danışmanlarının Suriyeli mülteci çocuklar adına hak savunucu rolünü üstlenmesi de kaçınılmaz görülmektedir.

Bir bütün olarak ele alındığında mültecilerin uyum süreçleri çok kapsamlı ele alınması gereken bir konudur. Bu çalışmada bu boyutlardan sadece biri olan eğitim ve özelde de çocukların okul ortamına sağlıklı uyumu üzerinde durulmuştur. Yapılacak çok şey olduğu aşikârdır. Son olarak, mültecilerin kültürel uyum süreçlerini kolaylaşmak adına insani ve ahlaki açıdan yoğun çaba sarf edilirken, toplumun adalet duygusunun sarsılmamasına özen gösterilmesinin de önemli olduğu düşünülmektedir. Her ne kadar adalet kavramını netleștirmek tarihsel süreçte kolay olmamıș olsa da (Balı, 2001), adaletsizlik kavramı birçok kişi için oldukça nettir. Bu bağlamda özellikle eğitim kurumlarında okul yöneticileri, öğretmenler, veliler ve öğrencilerin kaygıları sağlıklı bir şekilde giderilmeli, mültecilere toplumun adalet ve güven duygusunu sarsıcı imtiyazların tanınmasının önüne geçilmesine özen gösterilmelidir. Türkiye önemli bir öğrenme deneyimden geçmektedir ve 
öngörüldügü üzere süreç zorlu olacaktır. Bu süreci kolaylaştırmak adına ilgili tüm paydaşların üzerine ciddi sorumluluklar düşmektedir.

\section{KAYNAKÇA}

ACA Advocacy Competencies (2003). Advocacy competencies. http://www.counseling.org/ adresinden ulașilmıștır.

Apak, H. (2014). Suriyeli göçmenlerin kente uyumları: Mardin örneği. Mukaddime, 5(2), 53-70.

Apak, H. (2015). Suriyeli Göçmenlerin Gelecek Beklentileri: Mardin Örneği. Birey ve Toplum, 5, 125-142.

Balı, A. Ş. (2001). Çokkültürlülük ve sosyal a dalet. Öteki ile barış içinde yaşamak. Konya: Çizgi Kitapevi Yayınları

Banks, J. A. (2016). Çok kültürlü eğitime giriș (H. Aydın, Çev., Orijinal çalışma basım tarihi, 2007). Ankara: Anı Yayıncilik

Başbay, A. ve Bektaş, D. Y. (2009). Çokkültürlülük bağlamında öğretim ortamı ve öğretmen yeterlikleri. Eğitim ve Bilim, 34, 30-43.

Berry, J. W. (1997). Immigration, acculturation and adaptation. Applied Psychology: An International Review, 46, 5-68.

Berry, J. W., ve Sam, D. (1996). Acculturation and adaptation. İçinde J. W. Berry, M. H. Segall, \& C. Kagitcibasi (Eds.), Handbook of Cross-Cultural Psychology. Vol. 3, Social Behavior and Applications. Boston: Allynn \& Bacon.

Buz, S. (2008). Türkiye'deki sığınmacıların sosyal profili. Polis Bilimleri Dergisi,10 (4), 1-14.

Demirbaș, H. ve Bekaroğlu, E. (2013). Evden uzakta olmak: Sığınmacıların/mültecilerin psikolojik sorunları ve alınacak önlemler. Kriz Dergisi, 21 (1-2-3), 11-24.

Deniz, A.Ç. Hülür, A.B. ve Ekinci, Y. (2016). Göç, strateji ve taktik: Suriyeli sığınmacıların gündelik hayat deneyimleri. Uluslararası Sosyal Araştırmalar Dergisi, 9 (42), 1077- 1087.

Erdoğan, M. M. (2015). Türkiye'deki Suriyeliler: Toplumsal kabul ve uyum. Ankara: Hacettepe Üniversitesi Göç ve Siyaset Araștırmaları Merkezi Yayınları.

Esquivel, G. B. ve Keitel; M. A. (1990). Counseling immigrant children in the schools. Elementary School Guidance \& Counseling, 24, 3, 213-221.

Emin, M. N. (2016). Türkiye'deki Suriyeli çocukların eğitimi temel eğitim politikaları. Siyaset, Ekonomi ve Toplum Araştırmaları Vakfi. İstanbul: Turkuvaz Yayıncılık

Furnham, A. ve Bochner, S. (1986). Culture shock: Psychological reactions to unfamiliar environments. Routledge.

Greenberg Garrison E, Roy I.S., Azar V. (1999) Responding to the mental health needs of Latino children and families through school-based services. Clin Psychol Rev.; 19 (2), 199-219.

Gibson, R. L. ve Mitchell, M. H. (2016). Psikolojik danıșma ve rehberlik (S. Doğan (Ed.), D. Y. Kağnıcı, S. Koydemir ve Ö. Özü Cengiz, Çev., Orijinal çalıșma basım tarihi, 2011) Ankara: Nobel Yayıncılık.

Hayatboyu Öğrenme Genel Müdürlüğü (2017). Geçici süreli öğretici ve rehberlik danışman alımına ilişkin duyuru. http://pictes.meb.gov.tr/www/gecici-sureli-ogretici-ve-rehberlik-danisman-alimina-iliskinduyuru/icerik/18

İçişleri Bakanlığı Göç İdaresi Genel Müdürlüğü (2016). Göç istatistikleri. http://www.goc.gov.tr/ icerik6/ gecici-koruma_363_378_4713_icerik adresinden ulaşılmıştır.

Johnson, L. S: (2003) The diversity imperative: Building a culturally responsive school ethos, Intercultural Education, 14:1, 17-30, DOI:10.1080/1467598032000044629

Kara, Ö. T., Yiğit, A. ve Ağırman, F. (2016). Çukurova Üniversitesi Türkçe öğretmenliği bölümünde okuyan öğrencilerin Suriyeli mülteci kavramına ilișkin algılarının incelenmesi. Eğitimde Kuram ve Uygulama, 12(4), 945-961.

Karasu, M. A. (2016). Şanlıurfa'da yaşayan Suriyeli sığınmacıların kentle uyum sorunu. Süleyman Demirel Üniversitesi Iktisadi ve İdari Bilimler Fakültesi Dergisi, 21, 995-1014.

Kaya, .M. (2015). Komşuda misafirlik: Suriyeli sığınmacılarca kurulmuş mülteci derneklerinin perspektifinden Türkiye'de yaşamak. International Journal of Social Science, 39, 263-279.

Kaypak, Ş. ve Bimay, M. (2016). Suriye savaşı nedeniyle yaşanan göçün ekonomik ve sosyo-kültürel etkileri: Batman örneği. Batman Üniversitesi Yașam Bilimleri Dergisi; 6, 84-110.

Kopala, M., Esquivel, G. ve Baptiste, L. (1994). Counseling approaches for immigrant children: facilitating the acculturative process. The School Counselor, 41, 352-359.

Lewis, J. ve Bradley, L. J. (2000). Advocacy in counseling (Eds). Greensboro: Caps Publication.

Man,F . (2016). "Günah keçileri” ya da "Olağan şüpheliler" olarak Suriyeliler. Çalışma ve Toplum, 3, 1147-1170.

Milli Eğitim Bakanlı̆̆ı (2014). Yabancılara yönelik eğitim-öğretim hizmetleri. http://mevzuat.meb.gov.tr/ html/ yabyonegiogr_1/yabyonegiogr_1.html adresinden ulaşılmıştır. 
Mercan Uzun, E. ve Bütün, E. (2016). Okul öncesi eğitim kurumlarındaki Suriyeli sığınmacı çocukların karşılaştıkları sorunlar hakkında öğretmen görüssleri. Uluslararası Erken Çocukluk Eğitimi Çalışmaları Dergisi, 1,1, 72-83.

Migrant Integration Policy Index (2015). Turkey. http://www.mipex.eu/turkey

Önen, C, Güneş, G., Türeme, A. ve Ağaç, P. (2014). Bir mülteci kampında yaşayan Suriyelilerde depresyon ve anksiyete durumu. Akademik Sosyal Araştırmalar Dergisi, 6, 223-230.

Özer, S. ve Şirin, S. R. (2013). Suriyeli Mülteci Çocuklar-Saha Araştırması Sonuç Raporu. www.gib.icisleri.gov.tr/default_B0.aspx?id=180 adresinden ulaşıllmıştır.

Potttie, K. ve diğ. (2011). Evidence-based clinical guidelines for immigrants and refugees. www.cmaj.ca/content/183/12/E824.full adresinden ulaşılmıștır.

Rousseau,C. Lacroix, L., Bagilishya, D. ve Heusch, N. (2003). Working with myths: creative expression workshops for immigrant and refugee children in a school setting, Art Therapy, 20, 3-10.

Rousseau, C. ve Guzder, J. (2008). School-based prevention programs for refugee children. Child Adolesce Psychiatric Clinics of North America, 17, 533-549.

Sakız, H. (2016). Göçmen çocuklar ve okul kültürleri. Göç Dergisi, 2, 65-81.

Suriye'den İstanbul'a gelen sığınmacıları izleme platformu (2013): Yok sayılanlar; kamp ışında yaşayan Suriye'den gelen sığınmacılar İstanbul örneği. http://www.ihd.org.tr/yok-sayilanlar-kamp-disindayasayan-suriyeden-gelen-siginmacilar-istanbul-ornegi/ adresinden ulaşılmıștır.

Tuzcu, A. ve Bademli, K. (2014). Göçün psikososyal boyutu. Psikiyatride Güncel Yaklaşımlar ,6(1), 56-66.

UNICEF (2016). Türkiye'deki Suriyeli çocuklar bilgi notu. http://unicef.org.tr/files/bilgimerkezi/doc/T\%C3\%BCrkiyedeki\%20Suriyeli\%20\%C3\%87ocuklar_Bil gi\%20Notu\%20Nisan\%202016_1.pdf adresinden ulaşılmıştır.

Yaman, H., Kut, A., Yaman, A. ve Ungan, M. (2002). Health problems among UN refugees at a family medical centre in Ankara, Turkey. Scandinavian Journal of Primary Health Care, 20, 85-87.

Yohani, S. (2013). Educational cultural brokers and the school adaptation of refugee children and families: Challenges and opportunities. International Migration \& Integration, 14, 61-79, DOI 10.1007/s12134011-0229-x

Ward, C., Bochner, S., ve Furnham, A. (2001). The psychology of culture shock. Routledge.

A World at School (2015). Partnering for a better future: Ensuring educational opportunity for all Syrian refugee children and youth in turkey. http://www.aworldatschool.org. adresinden ulașllmıștır.

Topkaya, Y. ve Akdağ, H. (2016). Sosyal bilgiler öğretmen adaylarının Suriyeli sığınmacılar hakkındaki görüssleri (Kilis 7 Aralık Üniversitesi örneği). Çankırı Karatekin Üniversitesi Sosyal Bilimler Enstitüsü Dergisi, 7(1), 767-786. 